\title{
Indigenous Farmers' and Non-Farmers' Perceptions on Schooling and Human-Capital Development in Agro-Based Rural Communities in Southern Benue, Nigeria
}

DOI: 10.15804/tner.2015.42.4.12

\begin{abstract}
The presented study examined the impacts of schooling and human capital-development on agro-based rural communities in Southern Benue, Nigeria, from the perspectives of farmers and non-farmers. This study made use of the descriptive survey method. 1150 farmers and non-farmers were sampled using a multi-stage sampling technique. A researcher-designed questionnaire, interview schedule and observation technique were used for data collection. Mean rating and chi-square were used for data analysis. The results showed that schooling and human capital development (SHCD) had disorientated agro-based work-force in rural communities of Southern Benue, which was ranked $1^{\text {st }}$ with a mean score of 29.6 and the diversion of community resources towards schooling and human capital development (SHCD) instead of farming in rural communities of Southern Benue was ranked $2^{\text {nd }}$ with a mean of 28.8. Also, insignificant difference was found in the perspectives of farmers and non-farmers concerning the impacts of schooling and human-capital development on agro-based rural communities of Southern Benue, Nigeria. It was, therefore, concluded that schooling and human-capital development have created economic and social challenges, not development in the agro-based rural communities of Southern Benue, Nigeria. It is recommended that there is a need for the Government's strong commitment to addressing the paradox created by schooling in the human input used for sustaining productivity in the agro-based rural communities of Southern Benue, Nigeria.
\end{abstract}

Keywords: schooling and human-capital development (SHCD), agro-based communities, farmers, non-farmers 


\section{Introduction}

Many communities in Southern Benue, particularly rural communities, put faith in the schooling of their young ones because they hope that it would promote economic growth of the individual and society. In this study, positive social and economic changes are associated with the creation of qualitative citizenry through schooling that would benefit the rural communities. Human capital is a collection of resources involving: all the knowledge, talents, skills, abilities, experience, intelligence, training, judgment, and wisdom possessed individually and collectively by the populace. These resources are the total capacity of the people that represents a form of wealth which can be directed to accomplish the goals of the nation or state or a portion thereof. According to Gbenga \& Norhasni (2013), human capital development implies the acquisition of knowledge and intellectual stock through the means of education, for expansion of productivity, efficiency, performance and output. It is conceived that human capital plays the main role in economic growth, while the accumulated physical capital plays a secondary role. Countries accumulate human capital usually through formal training 'schools', research and development institutes, and learning-by-doing (in-service training) (Fadi, 2014). It is an aggregate economic view of the human being acting within communities, which is an attempt to capture the social, biological, cultural and psychological complexity as they interact in explicit and/or economic transactions.

The southern part of Benue state, Nigeria, as referred to in this paper, is the land area inhabited by the Idoma-speaking people. The majority of Idoma speaking people in Nigeria are found in Benue State, where they refer to themselves as "Idoma proper". With a population of about 941,621 people (National Population Commission, NPC, 2006), but now estimated to be about two million, they inhabit nine Local Government Areas in a Senatorial District. The Local Government Areas are Ado-Agatu, Apa, Ogbadigbo, Ohimini, Obi, Oju, Okpokwu and Otukpo (Amali, 2000).

The Idoma people are predominantly farmers who, with their Tiv brothers (to the North of Benue State), pride themselves on being called "The Food Basket of the Nation". Thus, agriculture and other economic activities still largely depend on what can be produced in the environment. The Idoma farmers produce crops such as yams, Guinea corn, maize, millet, cotton pepper, soya beans, rice, ginger, benne seed and other crops during the rain seasons. During the dry season they harvest, clear the bush in preparation for the next season (Amali, 2000). Farming is thus, a full life economic activity of the Idoma people. 
Western education and schooling in Southern Benue started in 1924 with the creation of a mission station at Igumale in the present Ado Local Government Area of Benue State. Since then, the demand for schooling has been increasing.

In this respect, schooling would have consciously or unconsciously shortcharged the active human labour, which hitherto has enhanced the economic production of the rural communities in Southern Benue. This is against the backdrop that an educated population is a productive population as opined by Babalola, (2005).

Education and schooling are two sides of the same coin called economic goods. The economist regards it as a consumer and capital good because it offers utility to a consumer and also serves as input into the production of other goods and services (Ayara, 2002, Garba, 2002). Thus, schooling as used in this study is an organic space proposed for teaching and learning, an institution or centralized location designed for teaching students or pupils under the supervision of teachers. In the Nigerian context, it is a formal system of education which is compulsory for all children aged 6-15 within the Universal Basic Education Scheme.

This makes it a process where students or pupils progress through a series of schooling institutions, some of which are Government or privately owned. Both Christian and Islamic religious organizations have been the forerunners in the development of the school system in Nigeria. Some scholars claim that schooling requires systematic methods of teaching which usually involve the use of a curriculum, a syllabus, an outline of work and a lesson plan (Ben 2006, Harris, 2006). In addition, they observed that typical schools have various areas, such as cafeteria ground, auditorium, library, laboratories, etc. (Rehman, 2008). Schooling has two purposes, which Rehman (2008) identified as practical and philosophical. The practical purpose of schooling is its usefulness to students or pupils, which can make them contributory citizens, workers, scholars and people in an increasingly complex society. These, he said, are derived through the contents taught in school. While in the philosophical context, schooling is designed to make intelligent choices and help pupils to make informal decisions. In Nigeria, schooling has become a foundation of hope for many parents who send their children to school because of the career opportunities it offers to its recipients. Human capital, on the other hand, represents the investment society makes in its members to enhance their economic productivity. Human Capital Development Theory concludes that investment in human capital will lead to greater economic outputs (Angela, 2009). In most communities, it is designed to bring about positive economic and social change, which would enhance productivity and large-scale production of goods and commodities. 
Babalola (2005) argued that the rationale behind schooling and human capital development is the need for people to be encouraged to develop entirely new ideas, products, processes and methods through creative approaches so as to introduce new processes, production and social services. Fadi (2014) applied human capital theory to justify large public expenditure on education across the globe, more so that it is consistent with the democratic principles of the Western world. Thus, the maxim "educate part of the community and the whole of it benefits" has become the central notion to the reason why most communities send their children to school. Ayara (2002) reported that education or schooling has not had the expected positive impact on the economic growth of the rural communities in Nigeria. It is with these incompatible views expressed by scholars and researchers that this study sought to examine the impacts of schooling and human capital development on the agro-based rural communities of Southern Benue.

\section{Purpose of the Study}

The general purpose of this study was to investigate farmers' and non-farmers' perceptions of schooling and human capital development in agro-based rural communities of Southern Benue. The specific aims were:

1. to examine the nature of the effect schooling and human capital development have on agro-based rural communities of Southern Benue in Nigeria.

2. to determine whether there are differences in the farmers' and non-farmers' levels of perception of schooling and human capital development in agrobased rural communities of Southern Benue.

\section{Research Questions}

The research questions for this study were as follows:

1. What is the nature of schooling and human capital development in the agro-based rural communities of Southern Benue, Nigeria?

2. Are there any differences in the perception levels of farmers and non-farmers regarding the effect of schooling and human capital development on agro-based rural communities of Southern Benue? 


\section{Research Hypothesis}

Ho1: There is no significant difference in the perceptions of farmers and non-farmers regarding the effect of schooling and human capital development on agro-based rural communities of Southern Benue, Nigeria

\section{Methodology}

The study adopted a descriptive survey method. The population of this study covered all farmers and non-farmers in Southern Benue. A total of 1150 participants, made up of 575 farmers and 575 non-farmers, were sampled with the use of the multistage sampling technique, i.e. a stratified random sampling technique at the $1^{\text {st }}$ stage and a simple random sampling technique at the $2^{\text {nd }}$ stage.

A researcher-designed questionnaire (with four Likert scale-type responses) was used to obtain data on schooling and human capital development in agro-based rural communities of Southern Benue. A structural interview and an observation technique were also used to enrich the data gathered.

Descriptive statistics (mean rating) were used to estimate the demographic data of the respondents and to provide answer to the research question posed, while inferential statistics (chi-square) were used to test the hypothesis formulated in this study at the 0.05 level of significance.

\section{Data Analysis and Results}

Analysis of the data obtained from 1150 respondents (575farmers and 575 non-farmers) and the results are presented below.

\section{Answering Research Question One}

Using a cut-off score of 2.50 as the baseline for determining the participants' responses, all the items (item1 to 10) were chosen and agreed on by the majority of the respondents, the mean score obtained from their responses in each item is above 2.50 as shown in Table 1 . This implies that schooling and human-capital 
development has a significantly negative effect on agro-based rural communities of Southern Benue.

Table 1. Mean and rank order of participants' responses concerning the effect of schooling and human-capital development in agro-based rural communities of Southern Benue, Nigeria

\begin{tabular}{clcc}
\hline No. & \multicolumn{1}{c}{ Items } & Mean & Rank \\
\hline 1 & $\begin{array}{l}\text { Schooling and human capital development have disorientated agro-based } \\
\text { work-force in rural communities of Southern Benue }\end{array}$ & 3.60 & $1^{\text {st }}$ \\
\hline 2 & $\begin{array}{l}\text { Community resources are being directed towards schooling and human } \\
\text { capital development instead of farming }\end{array}$ & 3.42 & $2^{\text {nd }}$ \\
\hline 3 & $\begin{array}{l}\text { Schooling and human capital development have led to rural-urban drift } \\
\text { of youths in rural communities of Southern Benue }\end{array}$ & 3.33 & $3^{\text {rd }}$ \\
\hline 4 & $\begin{array}{l}\text { Mass production of food has been reduced as a result of schooling and } \\
\text { human capital development in rural communities of Southern Benue }\end{array}$ & 3.04 & $4^{\text {th }}$ \\
\hline 5 & $\begin{array}{l}\text { The Agricultural Science subject as optional in schooling has shifted the } \\
\text { minds of community children from farming in rural communities of } \\
\text { Southern Benue }\end{array}$ & 2.94 & $5^{\text {th }}$ \\
\hline 6 & $\begin{array}{l}\text { Schooling and human capital development have prevented farmers from } \\
\text { inculcating the habit of manual work and farming in their children }\end{array}$ & 2.87 & $6^{\text {th }}$ \\
\hline 7 & $\begin{array}{l}\text { Schooling and human capital development have increased the cost of } \\
\text { living in rural communities of Southern Benue. }\end{array}$ & 2.72 & $7^{\text {th }}$ \\
\hline 8 & $\begin{array}{l}\text { Proficiency of youths in traditional practical skills have been affected as } \\
\text { a result of schooling and human capital development }\end{array}$ & 2.69 & $8^{\text {th }}$ \\
\hline 9 & $\begin{array}{l}\text { Schooling and human capital development have oriented the rural } \\
\text { communities of Southern Benue to other business activities instead of } \\
\text { faming. }\end{array}$ & 2.62 & $9^{\text {th }}$ \\
\hline 10 & $\begin{array}{l}\text { Government support for farming instead of education ought to be } \\
\text { increased. }\end{array}$ & 2.57 & $10^{\text {th }}$ \\
\hline
\end{tabular}

\section{$\underline{\text { Hypothesis Testing }}$}

As shown in Table 2, the - value is 321.212 with a p-value of 0.24 . Since the p-value of 0.24 is greater than the 0.05 level of significance, the null hypothesis is confirmed. This implies that there is an insignificant difference in the perceptions of farmers and non-farmers regarding the effects of schooling and human-capital development on agro-based rural communities of Southern Benue. 
Table 3. Chi-square analysis of farmers' and non-famers' perceptions of the effect of schooling and human-capital development on agro-based rural communities of Southern Benue, Nigeria

\begin{tabular}{|c|c|c|c|c|c|c|c|}
\hline \multicolumn{8}{|c|}{ Response Types } \\
\hline & S. Agreed & Agreed & Disagreed & S. Disagreed & df & $\chi^{2}-\mathrm{cal}$ & Sig. \\
\hline Farmers & 2246 & 2680 & 1237 & 1620 & & & \\
\hline & & & & & 4 & 463.677 & 0.24 \\
\hline Non-Farmers & 1333 & 2087 & 1246 & 2246 & & & \\
\hline Total & 3579 & 4767 & 2483 & 3866 & & & \\
\hline
\end{tabular}

$\mathrm{P}>0.5$

\section{Discussion of Findings}

Questionnaire items (items 1-10) were structured to elicit data from 1150 (575 farmers and 575 non-farmers) respondents regarding the effect of schooling and human-capital development on agro-based rural communities of Southern Benue.

The findings of the presented study revealed that schooling and human capital development had disorientated agro-based work-force in the rural communities of Southern Benue. This was ranked $1^{\text {st }}$ with a mean score of 3.60. The diversion of community resources towards schooling and human capital development instead of farming in the rural communities of Southern Benue was ranked $2^{\text {nd }}$ with a mean of 3.42. Also, schooling and human capital development have reduced mass production of food, affected proficiency of the youth in traditional practical skills, led to rural-urban drift of the youth, prevented farmers from inculcating the habit of manual work and farming in their children, increased the cost of living, diversified the business activities of rural communities, shifted the minds of community children from farming, reduced government support to farmers among others in the rural communities of Southern Benue. This finding is in line with Fadi (2014), who found that schooling and human capital development had negative effects on the agro-based environment. Thus, schooling and human capital development have affected the agro-based rural communities of Southern Benue, Nigeria.

The findings also revealed that there is an insignificant difference in the perceptions of farmers and non-farmers regarding the effect of schooling and human-capital development on the agro-based rural communities of Southern Benue. 


\section{Conclusions and Recommendations}

There is some ambivalence towards schooling and human capital development in the agro-based rural communities of Southern Benue. The paradox is that in spite of positive theoretical formulations that schooling and human capital development would stimulate growth and development of the rural communities, there is still under-employment, loss of workforce, low capacity for effective production of goods and scarce resources and a general disorientation of attitudes from their basic means of life sustenance, which is agriculture. These have created economic and social problems and no development in the agro-based rural community of Southern Benue as examined in this study.

There should be various policies to a responsive and functional education system that would help address the socio-economic needs of a rural society. As examined in this study, it is not an achievement that a negligible contribution is made to the economic growth of the rural communities which are not commensurate with the demand of human capital put into schooling by the rural communities.

Therefore, there should be the Government's strong commitment to addressing the paradox created by schooling the human input used for sustaining productivity in the agro-based rural communities of Southern Benue, Nigeria.

\section{References}

Amali, I.O.O. (2000). The influence of Western education on Idoma culture. Unpublished Ph.d. Thesis Maiduguri, University of Maiduguri.

Ayara, N.N (2002). The paradox of Education and Economic Growth in Nigeria: An Empirical Evidence. Selected Paper for the 2002 Annual Conference. Nigeria economic Society (NES) Ibadan.Polygraphic Ventures Ltd.

Babalola, J.B. (2003). Budget preparation and expenditure control in education, In Babalola J.B. (ed) basic text in educational planning. Awemark Industrial Printers.

Daramola, S.O. (2006). Sample and sampling technique. In Jimoh S.A. (ed) research Methodology in Education. Interdisciplinary approach, Ilorin, University of Ilorin.

Fadi, A.A. (2014). Human capital development in special economic zones: the case of Dubai. School of the Built Environment College of Science and Technology University of Salford, Salford, UK.

Federal Government of Nigeria (2004). University Nasic Education (U.B.E.). Federal Government Press, Abuja.

Federal Government of Nigeria (2005). National Population Commission (NPC) Federal Government Press Abuja.

Garba, P.K. (2002). Human capital formation, utilization and the development of Nigeria. 
Selected Paper for the 2002 Annual Conference of the Nigeria Economic Society (NES). Ibadan Poly graphic Ventures Ltd.

Gbenga M.A. \&Norhasni, Z.A. (2013). Human capital developments an interdisciplinary approach for individual, organization advancement and economic improvement. Asian Social Science, 9(4), 150-157

Hairs, D. (2006). The concept of school. Network Press.

Psacharopulos, G \& Woodhall, M. (1997). Education for development: An Analysis of investment Choice New York Oxford University press.

Rehman C, (1991). Economic growth in a cross section of countries: Quarterly Journal of Economic: 106(2) pp.407-414

Sakomata, A \& Powers, P.A (1995). Education and the dual labour market for Japanese man. American Sociological Review. (2002) pp.222-46

Schultz, T.W (1971). Investment in human capital. New York; the free press.

Smith, A(1976). An inquiry into the nation and causes of wealth of nation. Chicago University of Chicago press.

Van-Den-Berg, H. (2001). Economic growth and development (International Education) New York. MC GrawHiLL Companies, Inc. 